\title{
Penggunaan Model Pembelajaran Snowball Throwing untuk Meningkatkan Hasil Belajar Peserta Didik pada Pembelajaran Matematika Kelas VI SDN 99/X Sidomukti Semester Ganjil Tahun Ajaran 2021/2022
}

\author{
Anik Martiah \\ SDN 99/X Sidomukti \\ Jl.Putih Masurai RT.06 Desa Sidomukti, Sido Mukti, Kab. Tanjung Jabung Timur, Jambi. \\ anik_martiah@gmail.com
}

\begin{abstract}
The purpose of this study was to obtain information and discuss the use of the Snowball Throwing learning model to improve student learning outcomes in class VI mathematics learning at SDN 99/X Sidomukti in the odd semester of the 2021/2022 academic year. This type of research is classroom action research which consists of two cycles with each cycle consisting of four stages, namely planning, implementation, observation and reflection. This research was conducted at VI SDN 99/X Sidomukti in the odd semester of the 2021/2022 academic year with the research subjects being students of class VI SDN 99/X Sidomukti, totaling 20 students. Data collection techniques using tests, field notes, interviews, and documentation. Data were analyzed using percentages and data reduction. The results showed that the Snowball Throwing learning model could improve the mathematics learning outcomes of the sixth's grade students of SDN 99/X Sidomukti, marked by the improvement obtained from cycle I to cycle II.
\end{abstract}

Keywords: learning outcomes, math, Snowball Throwing

\begin{abstract}
Abstrak
Tujuan dari penelitian ini adalah untuk mendapatkan informasi dan membahas tentang penggunaan model pembelajaran Snowball Throwing untuk meningkatkan hasil belajar peserta didik pada pembelajaran matematika kelas VI SDN 99/X Sidomukti semester ganjil tahun ajaran 2021/2022. Jenis penelitian ini adalah penelitian tindakan kelas yang terdiri dari dua siklus dengan masing-masing siklus terdiri dari empat tahapan yaitu perencanaan, pelaksanaan, observasi dan refleksi. Penelitian ini dilaksanakan di VI SDN 99/X Sidomukti pada semester ganjil tahun ajaran 2021/2022 dengan subjek penelitian peserta didik kelas VI SDN 99/X Sidomukti yang berjumlah sebanyak 20 orang peserta didik. Teknik pengumpulan data menggunakan tes, catatan lapangan, wawancara dan dokumentasi. Data dianalisis menggunakan persentase dan reduksi data. Hasil penelitian menunjukkan bahwa melalui model pembelajaran Snowball Throwing dapat meningkatkan hasil belajar matematika peserta didik kelas VI SDN 99/X Sidomukti dengan ditandai dengan peningkatan yang didapat dari siklus I ke siklus II.
\end{abstract}

Kata kunci: hasil belajar, matematika, Snowball Throwing

Copyright (c) 2022 Anik Martiah

Corresponding author: Anik Martiah

Email Address: anik_martiah@gmail.com (Jl. Sultan Thaha, Sido Mukti, Kec. Dendang, Jambi)

Received 10 January 2022, Accepted 20 January 2022, Published 17 Februari 2022

\section{PENDAHULUAN}

Pendidikan merupakan salah satu hal yang terpenting dalam kehidupan manusia, karena pendidikan bisa mengubah pola pikir serta tingkah laku manusia menuju ke arah yang lebih baik. Pendidikan yang berkualitas akan menghasilkan lulusan-lulusan atau sumber daya manusia yang juga berkualitas begitu pun sebaliknya. Dengan adanya sumber daya manusia yang berkualitas diharapkan dapat memberikan kontribusi kepada bangsa dan negara.

Pemerintah telah meletakan dasar hukum yang kuat dalam menyelenggarakan pendidikan yaitu dengan dikeluarkannya Undang-undang No. 20 Tahun 2003 Bab 1 Pasal 1 (ayat 1) tentang Sistem Pendidikan Nasional. "Pendidikan adalah usaha sadar dan terencana untuk mewujudkan 
suasana belajar dan proses pembelajaran agar peserta didik secara aktif mengembangkan potensi dirinya untuk memiliki kekuatan spiritual keagamaan, pengendalian diri, kepribadian, kecerdasan, ahlak mulia, serta keterampilan yang diperlukan dirinya, masyarakat, bangsa, dan negara.

Salah satu pembelajaran di sekolah dasar yaitu pembelajaran matematika. Matematika merupakan salah satu disiplin ilmu dalam dunia pendidikan yang memegang peranan penting dalam pengembangan sains dan teknologi. Mata pelajaran matematika umumnya dianggap sulit bagi peserta didik dibandingkan mata pelajaran lainnya, terutama peserta didik di jenjang sekolah dasar. Anakanak MI/SD anak yang berada pada kisaran usia 7-12 tahun, menurut Peaget anak pada tahap ini masih berada dalam tahap berfikir operasional konkrit artinya bahwa peserta didik -peserta didik MI/SD belum bisa berfikir formal atau abstrak (Nursalam, 2013:8). Maka dari itu dalam pembelajaran matematika guru harus mampu memberikan pengetahuan kepada peserta didik, karena dalam belajar matematika berbicara tentang rumus dan symbol-simbol yang mungkin dianggap sulit oleh sebagian peserta didik.

Melalui pengamatan dan hasil evaluasi pembelajaran ditemui di kelas VI SDN 99/X Sodomukti tahun ajaran 2021/2022, guru masih banyak menggunakan metode yang didominasi metode ceramah yang menjadikan guru sebagai pusat kegiatan belajar mengajar atau teacher centered. Hasil observasi dan wawancara langsung yang dilakukan oleh peneliti di kelas VI SDN 99/X Sidomukti yaitu dalam kegiatan observasi masih banyak peserta didik yang masih kurang memahami materi pembelajaran matematika sehingga sulit menyelesaikan soal yang diberikan oleh guru dan cara guru dalam menyampaikan materi pembelajaran lebih sering menggunakan metode ceramah dalam menjelaskan materi serta kurang melibat langsungkan peserta didik dalam proses pembelajaran,

Berdasarkan permasalahan di atas maka diperlukan suatu metode pembelajaran yang mampu memfasilitasi peserta didik dan memecahkan masalah dalam pembelajaran di kelas VI SDN 99/X Sidomukti untuk mendapatkan pengalaman dan hasil belajar yang lebih baik yaitu metode yang memuat pengalaman belajar dan keaktifan peserta didik dalam kegiatan belajar mengajar. Salah satu metode yang dapat memuat keaktifan dan pengalaman belajar peserta didik tersebut adalah model pembelajaran kooperatif tipe Snowball Throwing.

Model pembelajaran Snowball Throwing adalah suatu model pembelajaran yang membagi peserta didik dalam beberapa kelompok, yang nantinya masing-masing anggota kelompok membuat sebuah pertanyaan pada selembaran kertas dan membentuknya seperti bola, kemudian bola tersebut dilemparkan kepada peserta didik yang lain selama durasi waktu yang telah ditentukan, selanjutnya masing-masing peserta didik menjawab pertanyaan dari bola yang diperoleh (Hamdayana, 2014:148). Jadi model pembelajaran ini merupakan model pembelajaran yang melibat aktifkan peserta didik dalam kegiatan pembelajaran, bekerja sama, dan menyenangkan. Dengan harapan memudahkana peserta didik dalam memahami materi pembelajaran terutama pada pelajaran matematika.

Berdasarkan permasalahan di atas maka peneliti mengadakan penelitian yang bertujuan dari penelitian ini adalah untuk untuk mendapatkan informasi dan membahas tentang penggunaan model 
Penggunaan Model Pembelajaran Snowball Throwing untuk Meningkatkan Hasil Belajar Peserta Didik pada Pembelajaran Matematika Kelas VI SDN 99/X Sidomukti Semester Ganjil Tahun Ajaran 2021/2022, Anik Martiah 751

pembelajaran Snowball Throwing untuk meningkatkan hasil belajar peserta didik pada pembelajaran matematika kelas VI SDN 99/X Sidomukti semester ganjil tahun ajaran 2021/2022.

\section{METODE}

Jenis penelitian ini adalah penelitian tindakan kelas yang terdiri dari dua siklus dengan masing-masing siklus terdiri dari empat tahapan yaitu perencanaan, pelaksanaan, observasi dan refleksi. Penelitian ini dilaksanakan di VI SDN 99/X Sidomukti pada semester ganjil tahun ajaran 2021/2022 dengan subjek penelitian peserta didik kelas VI SDN 99/X Sidomukti yang berjumlah sebanyak 20 orang peserta didik. Teknik pengumpulan data menggunakan tes, catatan lapangan, wawancara dan dokumentasi. Data dianalisis menggunakan persentase dan reduksi data.

\section{HASIL DAN DISKUSI}

\section{Siklus I}

\section{Perencanaan}

Perencanaan pada siklus pertama, peneliti menyusun kelengkapan yang berhunbungan dengan pembelajaran yaitu menyusun rencana pelaksanaan pembelajaran, menggunakan instumen soal ulangan peserta didik pada siklus pertama, lembaran pengamatan peserta didik dan guru selama proses pembelajaran dengan model tipe Snowball Throwing dan melengkapi sarana dan prasana yang berkaitan dengan pembelajaran.

\section{Pelaksanaan}

Pertemuan pertama siklus I dilaksanakan pada hari Rabu tanggal 29 September 2021 pada jam pelajaran ke 1-2. Pertemuan pertama membahas materi tentang Operasi Hitung Campuran. Tujuan pembelajaran pada pertemuan ini adalah "Setelah membaca data, siswa mampu menyebutkan bilangan sesuai nilai tempatnya dengan benar dan dengan menggunakan bilangan yang tersedia, siswa mampu mengurutkan bilangan dengan benar. Indikator pembelajaran pada pertemuan ini yaitu Menyebutkan bilangan sesuai nilai tempatnya dan Mengurutkan bilangan dengan benar. Pertemuan pertama terdiri dari tiga kegiatan yaitu kegiatan pendahuluan, inti ada penutup.

Selanjutnya pada kegiatan inti guru mengevaluasi kegiatan proses pembelajaran pertemuan sebelumnya, peserta didik dibagi menjadi 5 kelompok, setiap kelompok beranggotakan 4 orang, peserta didik mendengarkan penjelasan guru mengenai tugas yang harus dikerjakan, guru memanggil ketua dari setiap kelompok, setiap kelompok mendapatkan materi yang berbeda-beda tentang operasi bilangan campiuran yang diberikan oleh guru, ketua kelompok kembali ke kelompoknya masingmasing kemudian menyampaikan materi yang didapat dari guru kepada anggota kelompoknya, masing - masing peserta didik diberikan satu lembar kertas kerja untuk menuliskan satu pertanyaan yang menyangkut materi yang sudah dijelaskan oleh ketua kelompoknya kemudian kertas yang berisi pertanyaan tersebut dibuat seperti bola dan dilemparkan kepada kelompok yang lain. kelompok 1 dilempar ke kelompok 2, kelompok 2 dilempar ke kelompok 3, kelompok 3 dilempar ke kelompok 4 
dan seterusnya, setiap peserta didik harus mendapatkan satu bola atau satu kertas berbentuk bola yang berisi pertanyaan, peserta didik yang ditunjuk guru untuk berdiri kemudian membaca pertanyaan kemudian menjawabnya, peserta didik lain memberikan tanggapan atas jawaban temannya dan setiap kelompok merekap pertanyaan yang didapatkan kemudian dikumpulkan kepada guru.

Pertemuan kedua siklus II dilaksanakan pada hari Senin tanggal 4 Oktober 2021 pada jam pelajaran ke 3-4 dengan membahas materi tentang operasi bilangan campuran. Indikator pembelajaran pada pertemuan ini adalah menentukan bentuk operasi hitung campuran dan menyelesaikan soal dengan bentuk operasi hitung campuran. Tujuan pembelajaran pada pertemuan ini yaitu "Setelah membaca soal, peserta didik mampu menentukan bentuk operasi hitung campuran dengan benar dan setelah membaca soal, peserta didik mampu menyelesaikan soal dengan bentuk operasi hitung campuran dengan benar. Pertemuan kedua terdiri dari tiga kegiatan yaitu pendahuluan, inti, dan penutup. pelaksanaan pertemuan kedua sama halnya dengan pertemuan pertama.

\section{Observasi}

Sebelum pembelajaran pada pertemuan kedua siklus pertama dilakukan doa, maka dilakukan ulangan harian pertama pada siklus pertama, untuk mengetahui tingkat penguasaan peserta didik terhadap mata pelajaran matematika dengan menggunakan model pembelajaran kooperatif tipe Snowball Throwing. Hasil belajar peserta didik dapat dijelaskan pada tabel berikut ini:

Tabel 1. Rekapitulasi Hasil Tes Siklus I

\begin{tabular}{|c|l|c|}
\hline No. & \multicolumn{1}{|c|}{ Uraian } & Siklus I \\
\hline \hline 1 & Nilai rata-rata tes & 65.50 \\
\hline 2 & Jumlah peserta didik yang tuntas belajar & 11 \\
\hline 3 & Jumlah peserta didik yang tidak tuntas belajar & 9 \\
\hline 4 & Persentase ketuntasan belajar & $55 \%$ \\
\hline 5 & Persentase tidak tuntas belajar & $45 \%$ \\
\hline
\end{tabular}

Dari tabel di atas dapat disimpulkan bahwa dari 20 orang peserta didik hanya 11 orang peserta didik yang tuntas atau dengan persentase ketuntasan sebesar $55 \%$ yang masih berada di bawah kriteri ketuntasan yang diharapkan. Untuk itu perlu adanya perbaikan-perbaikan pada siklus berikutnya agar hasil belajar peserta didik meningkat lagi.

\section{Refleksi}

Sebelum melanjutkan pada siklus selanjutnya, maka dilakukan refleksi yang bertujuan untuk mengetahui tingkat keberhasilan dari pembelajaran yang telah dilaksanakan, baik dalam pelaksanaan pembelajaran oleh guru dan keaktivan peserta didik dalam pembelajaran maupun hasil belajar peserta didik. refleksi siklus I dilaksanakn pada hari Rabu tanggal 7 Oktober 2021 dibantu oleh seorang observer yang bernama Maisarah, S.Ag dan bertempat di ruangan kepala SDN 99/X Sidomukti. Refleksi pada siklus pertama adalah peserta didik kurang memahami bacaan dengan baik, peserta didik masih kesulitan dalam memahami isi bacaan. Masih ada peserta didik yang merasa bosan dengan pembelajaran matematika, ada beberapa peserta didik yang suka mengganggu teman yang lain sehingga pembelajaran tidak berlangsung secara maksimal, guru belum maksimal 
Penggunaan Model Pembelajaran Snowball Throwing untuk Meningkatkan Hasil Belajar Peserta Didik pada Pembelajaran Matematika Kelas VI SDN 99/X Sidomukti Semester Ganjil Tahun Ajaran 2021/2022, Anik Martiah 753

menciptakan suasana pembelajaran yang menyenangkan sehingga masih ada peserta didik yang menganggap pembelajaran matematika itu membosankan dan guru kurang memberikan motivasi kepada peserta didik .

Pada kegiatan siklus berikutnya guru harus membuat perencanaan pembelajaran yang lebih baik dan optimal, melaksanakan pembelajaran yang menyenangkan melalui bernyanyi dan permainan agar peserta didik tidak merasa bosan dan merasa senang, guru menjelaskan mengenai membaca pemahaman secara jelas dan berurut agar peserta didik dapat mengikuti dan melaksanakan pembelajaran dengan baik, pada saat pembelajaran, guru memberikan arahan dan bimbingan pada peserta didik dengan lebih optimal agar semua peserta didik dapat melaksanakan model pembelajaran kooperatif tipe Snowball Throwing dengan baik, guru harus memberikan teguran tegas namun sopan, apabila peserta didik melakukan kesalahan dan memberikan pujian serta penguatan apabila peserta didik mampu melaksanakan pembelajaran dengan baik. memberikan hadiah (reward) kepada peserta didik.

\section{Siklus II}

\section{Perencanaan}

Perencanaan pada siklus kedua, peneliti menyusun kelengkapan yang berhunbungan dengan pembelajaran yaitu menyusun rencana pelaksanaan pembelajaran, menggunakan instumen soal ulangan peserta didik pada siklus kedua, lembaran pengamatan peserta didik dan guru selama proses pembelajaran dengan model tipe Snowball Throwing dan melengkapi sarana dan prasana yang berkaitan dengan pembelajaran, memanajemen waktu kegiatan pembelajaran, membuat bola kertas yang warna warni, menyiapkan hadiah.

\section{Pelaksanaan}

Pertemuan pertama siklus II dilaksanakan pada hari Senin tanggal 11 Oktober 2021 dengan materi membahas tentang operasi hitung bilangan pecahan. Indikator pembelajaran yaitu enyebutkan makna bilangan pecahan dan membandingkan dan mengurutkan bilangan pecahan. Tujuan pembelajaran pertemuan pertama siklus II ini adalah "setelah membaca soal cerita, siswa mampu menyebutkan makna bilangan pecahan dengan benar dan setelah berdiskusi, siswa mampu membandingkan dan mengurutkan bilangan pecahan dengan tepat. Pertemuan pertama siklus II ini terdiri dari tiga kegiatan yaitu pendahuluan, inti, dan penutup.

Pada pelaksanaan tindakan perbaikan pembelajaran di awali dengan guru menyiapkan peserta didik, berdo'a, menanyakan kabar peserta didik dan presiensi peserta didik, pemberian motivasi dan melakukan kontrak kerja selama pembelajaran berlangsung, mengecek kesiapan belajar peserta didik, guru melakukan tanya jawab kepada peserta didik tentang materi pembelajaran yang telah lalu, guru menyampaikan tujuan pembelajaran yang akan dicapai, guru melihatkan serta menjelaskan alat peraga yang digunakan dan guru menyampaikan peserta didik yang memperoleh nilai sampai lima besar akan di beri hadiah. 
Pertemuan kedua siklus II dilaksanakan pada hari Rabu tanggal 13 Oktober 2021 dengan materi tentang operasi hitung bilangan pecahan. Indikator pembelajaran pada pertemuan ini yaitu menentukan bentuk operasi hitung campuran terkait pecahan dan menyelesaikan soal dengan bentuk operasi hitung campuran terkait pecahan. Tujuan pembelajaran pada pertemuan ini yaitu "Setelah membaca soal, siswa mampu menentukan bentuk operasi hitung campuran terkait pecahan dengan benar dan setelah membaca soal, siswa mampu menyelesaikan soal dengan bentuk operasi hitung campuran terkait pecahan dengan benar. Pertemuan kedua siklus II terdiri dari tiga kegiatan yaitu pendahuluan, inti, dan penutup.

Pelaksanaan tindakan di awali dengan guru menyiapkan peserta didik , berdo'a, menanyakan kabar peserta didik dan presiensi peserta didik, pemberian motivasi dan melakukan kontrak kerja selama pembelajaran berlangsung, mengecek kesiapan belajar peserta didik, guru melakukan tanya jawab kepada peserta didik tentang materi pembelajaran yang telah lalu, guru menyampaikan tujuan pembelajaran yang akan dicapai, guru melihatkan serta menjelaskan alat peraga yang digunakan dan guru menyampaikan peserta didik yang memperoleh nilai sampai lima besar akan di beri hadiah.

Kegiatan inti guru mengevaluasi kegiatan proses pembelajaran pertemuan sebelumny, guru menjelaskan materi pembelajaran, peserta didik menjawab pertanyaan guru materi pelajaran yang lalu, guru melakukan tanya jawab tentang materi tersebut, peserta didik dibagi menjadi kelompok, setiap kelompok beranggotakan 4 orang, peserta didik mendengarkan penjelasan guru mengenai tugas yang harus dikerjakan, guru memanggil ketua dari setiap kelompok, setiap kelompok mendapatkan materi yang berbeda -beda tentang operasi hitung campuran bilangan pecahan yang diberikan oleh guru, ketua kelompok kembali ke kelompoknya masing - masing kemudian menyampaikan materi yang didapat dari guru kepada anggota kelompoknya, masing-masing peserta didik diberikan satu lembar kertas kerja untuk menuliskan satu pertanyaan yang menyangkut materi yang sudah dijelaskan oleh ketua kelompoknya, kemudian kertas yang berisi pertanyaan tersebut dikumpulkan per kelompok masing - masing dilipat dan ditempelkan pada bola plastik dan balon, ketua kelompok-melemparkan bola ke kelompok yang lainnya, setiap kelompok membuka kertas yang tertempel pada bola plastic dan kertas dalam balon setiap peserta didik harus mendapatkan satu kertas berbentuk yang berisi pertanyaan, peserta didik yang ditunjuk guru untuk berdiri kemudian membaca pertanyaan kemudian menjawabnya, peserta didik lain memberikan tanggapan atas jawaban temannya, setiap kelompok merekap pertanyaan yang didapatkan kemudian dikumpulkan kepada guru, guru bertanya jawab tentang hal-hal yang belum diketahui peserta didik, guru memberikan penekanan terhadap materi, peserta didik diminta untuk merefleksi pembelajaran yang telah dilakukan.

Selanjutnya pada kegiatan penutup guru bersama-sama dengan peserta didik menyimpulkan materi pembelajaran, guru membimbing peserta didik dalam melakukan refleksi, guru memberikan soal ulangan kedua pada siklus kedua sebanyak sepuluh soal, guru memberikan hadiah kepada peserta didik yang memperoleh nilai sampai lima besar dan peserta didik yang lain diberikan hadiah yang 
Penggunaan Model Pembelajaran Snowball Throwing untuk Meningkatkan Hasil Belajar Peserta Didik pada Pembelajaran Matematika Kelas VI SDN 99/X Sidomukti Semester Ganjil Tahun Ajaran 2021/2022, Anik Martiah 755

lebih sedikit disbanding peserta didik yang nilai tertinggi, guru bersama peserta didik berdoa bahwa kegiatan perbaikan pembelajaran telah selesai.

\section{Observasi}

Setelah dilakukan perbaikan pembelajaran pada pertemuan kedua siklus kedua, maka dilakukan ulangan harian kedua pada siklus kedua, untuk mengetahui tingkat penguasaan peserta didik terhadap mata pelajaran matematika dengan menggunakan model pembelajaran kooperatif tipe Snowball Thro wing. Hasil belajar peserta didik dapat dijelaskan pada tabel berikut ini:

Tabel 2. Rekapitulasi Hasil Tes Siklus II

\begin{tabular}{|c|l|c|}
\hline No. & \multicolumn{1}{|c|}{ Uraian } & Siklus II \\
\hline \hline 1 & Nilai rata-rata tes & 78.50 \\
\hline 2 & Jumlah peserta didik yang tuntas belajar & 17 \\
\hline 3 & Jumlah peserta didik yang tidak tuntas belajar & 3 \\
\hline 4 & Persentase ketuntasan belajar & $85 \%$ \\
\hline 5 & Persentase tidak tuntas belajar & $15 \%$ \\
\hline
\end{tabular}

Dari tabel di atas dapat dijelaskan bahwa sebelum menerapkan model pembelajaran tipe Snowball Throwing di peroleh rata - rata hasil belajar peserta didik yaitu 78.50 dengan persentase 85 $\%$ atau 17 peserta didik dari 20 peserta didik yang tuntas belajar. Hasil tersebut menunjukkan bahwa pada pada siklus II secara klasikal peserta didik sudah tuntas belajar, karena hanya 3 peserta didik atau hanya sebesar $15 \%$ yang berada di bawah KKM.

\section{Refleksi}

Tahap refleksi siklus II dilkasanakan pada hari Sabtu tanggal 16 Oktober 2021 dengan dibantu olh seorang observer yang bernama Maisarah, S.Ag. dan bertempat di ruangan kepala SDN 99/X Sidomukti. Refleksi pada siklus kedua terjadi perubahan yang baik dari pada siklus sebelumnya, hal ini terjadi perubahan pada diri guru dan peserta didik dalam proses pembelajaran antara lain peserta didik dapat memahami bacaan dengan baik, peserta didik dapat dalam memahami isi bacaan. Peserta didik yang tidak merasa bosan dengan pembelajaran ilmu pengetahuan social, siwa terlihat bersemangat dan termotivasi dalam pembelajaran.

Guru telah melaksanakan pembelajaran yang menyenangkan, guru menjelaskan mengenai membaca pemahaman secara jelas dan berurut agar peserta didik dapat mengikuti dan melaksanakan pembelajaran dengan baik, guru memberikan arahan dan bimbingan pada peserta didik dengan lebih optimal agar semua peserta didik dapat melaksanakan model pembelajaran kooperatif tipe Snowball Throwing dengan baik, memberikan hadiah kepada peserta didik dan hasil belajar peserta didik rata-rata telah mencapai KKM.

\section{Diskusi}


Berdasarkan hasil penelitian terdapat peningkatan hasil belajar matematika peserta didik kelas VI SDN 99/X Sidomukti pada semester ganjil tahun ajaran 2021/2022 melalui model pembelajaran Snowball Throwing. Keaktivan peserta didik selama proses pembelajaran ditunjukkan dengan peserta didik sudah aktif dan mendengarkan penjelasan materi serta mengikuti semua arahan dari guru, peserta didik sudah berpendapat dalam menjawab pertanyaan saat berdiskusi, peserta didik sudah mengolah atau menggabungkan dengan pendapatnya sendiri, peserta didik terlihat termotivasi dalam pembelajaran dan tidak terdapat sifat acuh tak acuh serta mengganggu teman satu kelompok.

Model pembelajaran Snowball Throwing merupakan pngembangan dari model pembelajaran diskusi dan merupakan bagian dari model pembelajaran kooperatif, hanya saja pada model ini kegiatan belajar diatur sedemikian rupa sehingga prose belajar mengajar dapat berlamgsung dengan lebih menyenangkan. Snowball Throwing adalah model pembelajaran yang memberikan pengalaman kepada siswa melalui pembelajaran terpadu dengan menggunakan proses yang saling berkaitan dalam situasi dan konteks komunikasi alamiah baik sosial, sains, hitungan dan lingkungan pergaulan. Sehingga dengan menerapkan pembelajaran Snowball Throwing peserta didik diajak untuk berpartisipasi secara aktif selama proses pembelajaran dengan begitu peserta didik akan berminat mengikuti pembelajaran (Nurul:2016).Dibentuk kelompok yang diwakili ketua kelompok untuk mendapatkan tugas dari guru kemudian masing- masing ketua kelompok kembali keanggotanya untuk menyampaikan materi kepada teman-temannya, lalu membuat pertanyaan yang dibentuk seperti bola (kertas pertanyaan) dan kemudian dilempar ke peserta didik lain yang masing-masing peserta didik menjawab pertanyaan dari yang diperoleh.

\section{KESIMPULAN}

Dari hasil penelitian dan pembahasan dapat disimpulkan bahwa penggunaan model pembelajaran Snowball Throwing dapat meningkatkan hasil belajar peserta didik pada pembelajaran Matematika kelas kelas VI SDN 99/X Sidomukti semester ganjil tahun ajaran 2021/2022. Hal ini ditandai dengan adanya peningkatan persentase ketuntasan dari siklus I (55\%) ke siklus II ( $85 \%)$.

\section{REFERENSI}

A, Suprijono. 2010. Cooperative Learning. Yogyakarta: Pustaka Media

A.M Sardiman. (2009). Interaksi dan Motivasi Belajar Mengajar. Jakarta: PT. Rajawali. Pers.

A.M, Sardiman. (2007). Interaksi dan Motivasi Belajar Mengajar. Jakarta: Raja. Grafindo Persada.

Abdur Rahman Dkk. 2000. Memahami Dan Menangani Peserta didik dengan Problem Belajar. Jakarta: Depdiknas.

Agus, Suprijono. (2012). Cooperative Learning: Teori dan Aplikasi Paikem. Yogyakarta: Pustaka Pelajar

Ajang Mulyadi. (2002). Akuntansi Manajemen. Program Studi Akuntansi:Universitas Pendidikan Indonesia. 
Penggunaan Model Pembelajaran Snowball Throwing untuk Meningkatkan Hasil Belajar Peserta Didik pada Pembelajaran Matematika Kelas VI SDN 99/X Sidomukti Semester Ganjil Tahun Ajaran 2021/2022, Anik Martiah 757

Azhar Arsyad. (2013). Media Pembelajaran. Jakarta: Rajagrafindo Persada.

Bayor. 2010. Penerapan Metode Snowball Throwing Dalam Pemelajaran Pendidikan Kewarganegaraan (Pkn). Jakarta

Campbell, N.A. \& J.B. Reece. (2008). Biologi, Edisi Kedelapan Jilid 3. Terjemahan: Damaring Tyas Wulandari. Jakarta: Erlangga

Dimyati dan Mudjiono. (2006). Belajar dan Pembelajaran. Jakarta: PT Rineka Cipta

Hamalik, Oemar. (2004). Proses Belajar Mengajar. Jakarta: Bumi Aksara.

Jumanta Hamdayana. (2014). Metode dan Model Pembelajaran Kreatif dan Berkarakter. Cet:1. Bogor: Ghalia Indonesia

Kagan. 1994. Cooperative Learning in Social Studies. California: Arizona State

Mustaqim dan Abdul Wahib. (2010). Psikologi Pendidikan. Jakarta: Rineka Cipta.

Nana Syaodih Sukmadinata. (2011). Metode Penelitian Pendidikan. Bandung: PT Remaja Rosdakarya.

Nasution, S. (1999). Kurikulum dan Pengajaran. Jakarta: Bumi Aksara

Nursalam. (2013). Strategi Pembelajaran Matematika Teori Dan Aplikasi Bagi Mahapeserta didik PGMI. cet:1, Makassar, Alauddin University Press.

Nurul Fatimah, Azhar, Mitri Irianti. (2016). Penerapan Pembelajaran Snowball Throwing Untuk Meningkatkan Minat Belajar Siswa Dalam Pembelajaran IPA Fisika Kelas VII SMPN 20 Pekan Baru

Slameto. (1995). Belajar Dan Factor-faktor Yang Mempengaruhinya. Jakarta: $\quad$ Rineka cipta. Slameto. (2010). Belajar dan Faktor yang mempengaruhinya. Jakarta: Rineka. Cipta.

Sudjana, Nana. (2009). Penilaian Hasil Proses Belajar Mengajar. Bandung: PT. Remaja Rosdakarya Sudjana, Nana. (2002). Penilaian Hasil Proses Belajar Mengajar. Bandung: Remaja Rosdakarya Trianto. (2009). Mendesain Model Pembelajaran Invatif-. Progresif. Jakarta: Kencana Prenada Group. 